\title{
The imaginary of plasticity: neural embodiment, epigenetics and ecomorphs
}

Dimitris Papadopoulos

\section{Abstract}

Every epoch has its brain. The embodied brain seems to be today at the forefront of attempts to establish post-positivistic approaches in social science and social theory as well as non-reductionist conceptions of the brain and body in neuroscience, developmental science and psychology. But embodiment not only challenges prevalent epistemic and cultural assumptions in these disciplines; it also opens avenues for exploring the plasticity and the emergent epigenetic nature of the brain and body. Plasticity occupies the brain-body imaginary of today's epoch. At the heart of the imaginary of plasticity lies the possibility of recombining brain-body matter and understanding the making of ecologically dependent morphologies in a non-determinist manner. But plasticity as recombination becomes not only a radical challenge to prevailing determinist assumptions about the brain-body in Western thought, it becomes also a forceful element of its own regeneration and actualization. 


\section{Recombination and plasticity}

Every epoch has its brain. And every epoch fantasises a better brain than the one it has. Today, one can see early signs of a shift from a cognition oriented and centralised brain dominating research for many decades towards an extended, connected and most importantly embodied understanding of the brain, towards the brain-body. In neuroscience, developmental science and psychology the concept of embodiment is used to grasp the idea that mental and brain processes are embedded in a material body and in a structured environment. In social science, cultural theory and social theory embodiment is employed to address questions of difference by foregrounding the socio-cultural making of the body and of experience.

In both, though often very disparate, disciplines embodiment is presented as an answer to the shortcomings of the sciences of the brain which have treated the brain as a self-contained, decontextualized entity; an answer to the shortcomings of genocentric deterministic approaches which have neglected the role of the environment; and finally embodiment appears as an answer to the shortcomings of various essentialist conceptualizations of difference, primarily gender and race, and the untenable foundationalism of related political movements. The concept of embodiment appears to exercise an almost therapeutic function: it promises to heal the deep discontent within 'Western thought' (cf. Lakoff and Johnson, 1999).

This piece explores connections and mutations of these various usages of the concept of the embodied brain in relation to the shifting cultural and political imaginaries of societies in the Global North. I argue that these shifts pertain to a new master narrative of changing the brain-body which thrives on the technoscientific ambition to monitor, control and transform processes of life on the very level of their material composition. 'Today we are learning the language in which God created life' declared President Clinton in his announcement on the decoding of the human genome on Monday 26th June 2000. As I could not not recall Wittgenstein's (1958) canon at this moment - that language exists only when it is actively used - a daunting vision appeared to me: practicing the language of creation. Secular creationism. The ability to recombine brain-body matter and to produce new sociomaterial forms of existence.

The underlying presupposition of conceiving brain-body matter as amenable to recombination is that it characterised by plasticity. But plasticity is not a new concept as such; it has a long history in neuroscientific research and traditional brain research. The question is what kind of plasticity is assumed here. Today's plasticity starts where the gene stops: the specificity of the individual organism. Plasticity appears when epigenetics is at work: the worldly making and remaking of the totality of an organism in the process of its development. Rather than just the relative malleability of brain matter, plasticity now refers to the possibility of recombining brain-body matter. Not as an abstract and general process of neuronal regeneration but as a process that takes place epigenetically, that is according to the specific and contingent realities of each particular organism. 'Genes and genius: Does everyone have the potential to be a genius? Epigenetics offers hope for us all' is the title of a review of David Shenk's (2010) popularisation of epigenetics for everyone in the New Scientist (27 March 2010: 51). This understanding of plasticity sneaks in to the cultural imaginary of the body and brain of the Global North as a promise. And as a practice: In the near future we will be able to create new neurons 'at will, where and when you need them' (Horstman and Scientific American, 2010: 5). Neuroplasticity as neurogenesis from below. 
In this piece I collect various materials that can furnish a historical reconstruction of conceptualisations of the brain-body from the vantage point of its understanding as plastic and amenable to recombination. This is a speculative story in which previous conceptualisations and visions of the brain-body are read through the prism of recombinant plasticity. Such a story has of course many limitations - its linearity seems to be the most apparent one - but at the end it is nothing else than an experiment: if every epoch has its brain and if the recombinant plastic brain is the brain to come then the aim of this piece is to fabulate by telling a partial story of the recombinant plastic brain's own history through its own eyes. The next section discusses various existing cultural imaginaries of the brain-body exploring how the embodied brain modifies them and comes to become the prevalent vision of the brain-body today. The sections that follow trace the links between these imaginaries and the epistemic genealogy of embodiment and recombinant plasticity. Section II discusses the move from behaviourism to cognitivism and then to connectionism. Connectionism was crucial for preparing the ascent of theories of embodiment. Section IV focuses on different approaches to the embodiment of the brain and its relation to experience. Section $\mathrm{V}$ investigates the relation of embodiment to culture and polity of contemporary societies. In the same way that cognitivism and connectionism prepared the way for the emergence of embodied approaches, section VI argues that embodiment opens the view towards an understanding of the brain and body as recombinant and plastic. Section VII reviews epigenetics and ecomorphs as two manifestations of the developmental and ecological plasticity of the brain-body. The concluding section of the paper raises possible political implications of the imaginary of recombinant plasticity.

\section{The cultural ordering of the embodied brain}

How is the embodied brain-body situated in relation to other existing brain-body cultural topoi. Topos is a conventional place, it refers to common topics of reference; but topos is not about common themes and motifs of argumentation which we deploy, it also refers to the idea of place as concrete socio-material space where processes of materialization take place (Barad, 1998). Topos refers equally to symbolic commonality (shared meaning) and to material space (lived place). Topos is the place where we physically convene to partake in dealing with common concerns. In this sense, each different brain-body topos constitutes a specific semiotic and material arrangement that is historically and culturally limited and that operates as a space of interaction, conflict and negotiation over the making and remaking of our brain-body. In particular, theories of embodiment come and add themselves to the arena of other topoi (s. Gilbert, 1997; cf. also Bordo, 1990; Frank, 1991; Haraway, 1991; Martin, 1992), engage with them, challenge them, and participate in the creation of new social and material realities and imaginaries than these that existed before.

Probably the most powerful of these cultural imaginaries of the brain-body is the topos of the cerebral body: the body which exists as the carrier of the intellect, as the site of cognition. The question of the materiality of the cerebral body is a question of inferior importance; its logic is based on taming, suppressing, canalizing brain energies and bodily feelings. Flesh has to be controlled because it is the 'source of epistemological error, moral error, and mortality' (Csordas, 1994a: 8; s. also Leder, 1990). The cerebral body celebrates exuberant production of knowledge and deploys it to control the complex processes of its own physicality and materiality. The cerebral body pretends to 
be universalist, normative, expansive, gender-free and culture-free. It searches for brain modules (Fodor, 1983; Scholl and Leslie, 1999), for deterministic procedures, for fixed algorithms in order to identify the normal ideal brain/body. The cerebral body is the value producing body, the flesh which has use value, the able body - as opposed to the non-productive and disabled body, whose corporeality has always to be corrected (cf. Breckenridge and Vogler, 2001).

A parallel body topos focuses on a different type of control: the immune body is obsessed with protection, with the creation and maintenance of boundaries. The topos of the immune body is concerned with prediction of possible damages and contaminations; it concentrates on the techniques of repair, normalization and segregation. In the topos of the immune body, research aims to demarcate the limits of the body, its durability, its widths of tolerance. The immune body 'is a body that separates us from the other bodies that inhabit the globe and that prohibits our fusing with other entities. The immune body is that which determines our Hobbesian selfness and is in potential conflict with every body' (Gilbert, 1997: 38). The immune body is primarily concerned with the production of knowledge which conserves and defends, which opposes weakness, which anticipates what is essential for protection and preservation of the body's processes. 'What we need to do better is be predictive. We have to be proactive. We have to develop the capability to anticipate attacks. We have to develop the capability of looking around corners. And that is the change. That is the shift in focus particularly at headquarters' in the words of Robert S. Mueller III, Director of the U.S. Federal Bureau of Investigation after the New York events of 9/11 (Mueller III, 2002).

The immune body is obsessed with the threat of sudden death. But death here is not considered as a natural phenomenon, it is a process which can be forced from outside, it designates the break down of the body's boundaries. Death can be anticipated, prevented and the immune body's main task is to pre-empt death. The temporal register of the immune body is the future. The future is open to vulnerabilities, the future is the reservoir of possible threats that can trigger the body's implosion, dissolution and death. For example, when HIV erupted in Western gay communities in the mid 1980s, it initially triggered a moral panic, not over the actual deaths it caused, but over what it suggested about the vulnerability of the body - and of the body politic (Martin, 1990). HIV become a signifier of how gay men subverted the masculinist fantasy of the intact body underpinning the heterosexual matrix (Crimp, 1988; Weeks, 1995). A fantasy that assumed that masculine bodies are immune, protected, impenetrable (Irigaray, 1985; Roberts et al., 1996) in the same way that nation states are assumed to be controlled and sovereign territories. The topos of the immune body is less about the negation of this vulnerability and more about anticipating how to avoid them, how to avoid potential infection, disease and death. The immune body is plagued by fear.

The only antidote to fear is to exit the materiality of the body altogether. This is the topos of the discarnate body which provides this exit, relief from the vulnerability of the flesh. The discarnate body introduces the fantasy of the pure self, incorporeal, fleshless, liberated from the passions, habits, and weakness of its facticity. The discarnate body is the home of pure ideas, clean thoughts, uncontested intellectuality. Against the immune and cerebral body topoi which concentrate on the production of different types of knowledge, the discarnate body cultivates sanctity. Rather than producing knowledge to tame the body or to protect it, the discarnate body is the site of faith. The discarnate body is less about exploring and experimenting with its immanent functions, origins and boundaries and more about confidence in some transcendent order and purpose of the body. The 
discarnate body is orientated towards a temporality which is outside of lived time. Its powerfulness lies with the authoritative effect this infinite temporality has on everyday practical commitments.

In the topos of the discarnate body time is infinite while the universal cerebral flesh is a place without time, out of time. The topos of the immune body is defined by the synchronic affections between different bodies. The diachronic axis, the evolutionary history of flesh, is captured in the topos of the hereditary body: the search for genetic algorithms, for the ultimate code of development (Dennett, 1995). The hereditary body is the body which is the result of gene expression; it purports to tell the objective natural history of the flesh. The hereditary body is the body which marks and categorises origins: it is the topos in which gender is constructed as sex, it is the topos in which the racialisation of peoples of colour and migrants unfolds, it is the topos which cultivates the saga of deep belongings (nation, language) through supposed common body architectures. The hereditary body is concerned with time past, it sees the future as a continuation of its given evolutionary roots, it attempts to diminish the synchronic pressures on the brain and the body and to minimize uncertainty.

What is common to all these temporal registers is that the flow of time is external to the body. It constitutes the background against which each of these different body imaginaries occur. In all these temporal orders time is pre-existent, it is a neutral trajectory that runs quasi objectively and uniformly independently of the actually changing brain-bodies. But if we think of time as a creative force, not as just a neutral trajectory but as an intensive element in brain-body's metamorphoses, then a different cultural vision of the brain-body appears: the topos of emergence. If we 'temporalize time' itself (Sandbothe, 1998), the brain-body becomes simultaneously the subject and object of its own regeneration. The emergent brain-body responds on the one hand to formations of life which evolve as the time of life flows and creates new unpredictable and novel configurations of existence. This real lived time is the time of development: the emergent body exists in the realm of its own developmental trajectory and actuality (Gilbert and Epel, 2009; Gottlieb, 1997). On the other hand it is emergent because the creation of new forms is always limited by the actually existing contingent conditions of existence (for an extended discussion of emergent architectures of being see Cooper, 2008; and Chapters 8 and 9 in Papadopoulos, Stephenson, and Tsianos, 2008). The emergent and embodied brain-body is unthinkable, indeed impossible to exist, outside of the formative chronotope of ontogenesis. If the hereditary body conjugates the notion of predisposition in different versions (cf. Gould, 1977), the emergent body refers to how lived ecologies shape the brainbody iteself. The imaginary of the emergent brain-body has a strong resemblance with Deleuze and Guattari's (1987) understanding of nomadism as a state of openness of a body to its own construction through its movements, rather than through an externally imposed form of organisation.

\section{From cognitivism to connectionism}

These different cultural imaginaries of the brain-body are tightly interwoven with existing epistemic languages and practices of the brain-body. While every epoch has its brain, not every epoch considers the brain as the seat of thinking and consciousness. In ancient Greece the higher parts of the soul reside in the heart; similarly, traditional Chinese medicine sees the heart as the house of the mind; Descartes considered the pineal gland as the seat of thinking. With the rise of medicine in the mid- 
end of the $19^{\text {th }}$ century that the brain becomes a systematic object of study. But even then the brain is far from being the seat of thinking and consciousness. Until the 1950s the functions and the psychology of the brain are black-boxed through the dominance of behaviourism. With the dispute over the ultra positivistic Skinnerian program the behaviourist mechanistic Stimulus-Response (S-R) model comes gradually under attack. The main task is to rehabilitate the very idea of 'thinking' in psychological and brain research. There were many predecessors to this endeavour (e.g. Woodworth, 1921, 1938) since behaviourism's expulsion of thinking from psychology at the beginning of the $20^{\text {th }}$ century (J. B. Watson, 1913). Dewey's (Dewey, 1999; see also Baldwin, 1897) vision of the mind as a social process contested the behaviourist view of mind and thinking. In the first decades of the $20^{\text {th }}$ century pragmatism presented a viable and lively alternative to the obliteration of thinking, cnsciousnees and experience in dominant academic discourses but could not challenge the dominance of the behaviourist model. It is only much later that pragmatism's approach informed research on the brain-body through its influence on certain strands of connectionism and embodiment. In this moment, however, none of these endeavours precipitated a fundamental turn in research on mind and consciousness, such as the one which took place with the rise of cognitivism in the 1950s.

E.Ch. Tolman (1954) was among those who formulated basic outlines for the new trend in research on thinking few decades before the emergence of the cognitivist movement. He introduced the idea of 'intervening variables' which was an attempt to dissect the entire phenomenon of behaviour in order to achieve a new homogeneous synthesis. The response is no more a linear, direct correlate of the stimulus that takes place after a certain time lag. It is a function of the stimulus that depends on the environment, the need system and the belief-value matrix of the individual. The internal plane of human consciousness becomes the core centre for the regulation of behaviour.

Emphasizing the idea that thinking is a function was a key moment for the emergence of cognitivism. For example, Jerome Bruner, one of the protagonists of the cognitive turn, saw a possibility for derailing behaviourist dominance in the insertion of a new middle link in the S-R pattern that would allow the investigation of this internal plane of thinking. This link was the 'signmediated-thought' (Bruner, 1967). Thinking is elucidated as an organon with specific functions. The 'output' of a certain 'input' is no longer immediately predictable, but is now mainly a function of thinking. But, with the suspension of prediction, the scientistic presuppositions required to assert the natural scientific character of research seem to vanish. In the mid fifties - a period in which significant publications (by Chomsky, Newell, Simon etc) and events (such as the MIT Symposium on Information Theory) in the history of cognitivism took place (Gardner, 1987: 28) - Bruner, Goodnow and Austin (1956) publish A Study of Thinking. Here they proclaim that rule-learning, categorization, and processes of abstraction are the main functions of thinking. Thinking is not only about representing, but mainly about problem solving, it is a function. The quest becomes then how to visualise the 'invisible' domain of this functions. The answer to this was the idea of computionalism: cognitive processes constitute a standard set of procedures which can be reduced to pre-defined lower level processes (Churchland, 1986). Cognition emerges in 'patterns of data and in relations of logic that are independent of the physical medium that carries them' (Pinker, 1997: 24).

Even if cognitivism is still the dominant paradigm of research in the field of psychology and neuroscience, there is an increasing focus on producing systematic knowledge of somatocognitive processes which can be generalized without relapsing into the universalism and essentialism of 
computationalism. One could read experimental neuroscience's obsession with mapping psychological functions and subjectivity on the brain (Beaulieu, 2003; Dumit, 2004; Joyce, 2005) as another step in the long history of localizationism (Star, 1989) that attempted to uncover how the relation between mind and brain is constituted. The brain mapping of subjectivity through new visualisation technologies that correlate psychological functions with brain areas seems to perpetuate a traditional abstract view of the brain as a fully formed, static modular structure (Littlefield, 2009; Karmiloff-Smith, 1992). But it also reveals an attempt to go beyond the use of embodiment as a figural or metaphoric concept - even if this usage is fruitful and certainly also inexorable, as I will argue later - in order to sketch direct relations between experiential processes and intersubjectivity to the material workings (i.e. brain activity and neurobiological processes) of the body (cf. Cromby, 2007; Franks, 2010; Scott, 2001).

In this attempt connectionism represents an important step in moving away from cognitivism towards an understanding of the embodied brain. Connectionism promises the possibility of unravelling the structural relations between perception, cognition, action and affect by conceiving all these dimensions of existence as linked directly on the neuronal infrastructure of the brain. Connectionist research in experimental neuroscience (e.g. Thelen and Smith, 1994; Liben, 1999; Wilson, 1998) visualises the embodiment of the brain on the material-neurobiological level. Neuronal networks depict complex assemblies of interconnected nerve cells where certain synapses constitute central nodes in the network while other occupy more peripheral positions. The process of ontogenetic development sees the birth, change and decline of many such connectionist nets materialised through the webs of neurons (Changeux, 1997; Edelman, 1989; Edelman and Tononi, 2000).

A crucial change that connectionist modelling introduces is the questioning of 'representational nativism' that is prevalent in cognitivist approaches: cortical development depends on genetically driven microcircuitry that accounts for the organisation of brain functions. Mental representations in cognitivism are the result of innate neurophysiological processes that are context independent and universal in the human brain. Thinking has universal algorithmic structure and resides in fixed neuronal architectures. Against all this '[i]n a connectionist network, representations are patterns of activations across a pool of neuron-like processing units. The form of these activation patterns is determined by the nature of the connections between the units. Thus, innate representational knowledge ... would take the form of prespecified weights on the inter-unit connections' (Elman et al., 1996: 25). What is crucial in connectionism is that the weighting of the nodes is not given but emerges through learning. This is the moment where the idea of a malleable brain matter that its characterised by its emergent qualities and its dependence on the surroundining environment comes to being. While computationalism presupposes innate neuronal structures, connectionism presupposes semi-open, nonlinear architectures that unfold during the very process of ontogenetic development. Brain matter is simultaneously the actor and the result of its own activity. Brain matter becomes formed as it becomes active, but it is active only because this activity shapes the brain into specific forms. Connectionism is a crucial move away from the essentialism and universalism of cognitivism; the formation of brain matter is emergent, that is contextual: it depends on the intra-organismic and extra-organismic ecosystems. This move prepares a conceptualisation of brain matter as embodied. 


\section{Experience and embodiment}

The embodied approach adds a significant dimension to connectionist modelling of the brain. Embodiment is not only about the syntactic structures of meaning but also aims to encompass the semantics of experience - the production of meaning - and the pragmatics of experience - that is context-dependent and culture-dependent aspects of meaning. Context and experience merge into the workings of brain matter. It is not a coincidence that social, cultural and critical psychological theories of embodiment engage with the study of the brain-body relation: existentialism and phenomenology (Heidegger, 1993; Merleau-Ponty, 1966), social constructionism (Cromby, 2004) and cultural-historical psychological accounts (Vygotsky, 1987; Wygotski, 1987; see also Papadopoulos, 2010c). The embodiment of brain matter means that mental functions are not formal procedures; cognition is not independent of its implementation; mind and experience is always instantiated in concrete material structures: in a body (Damasio, 2004; Lakoff and Johnson, 1999; Varela, Thompson, and Rosch, 1991), in an environment (Clark, 1997; Edelman, 1992; Lewontin, 2000a; S. Rose, 1998), in a social context (Csordas, 1994b; Harré, 1996; Overton, 1998; Sampson, 1996), or in cultural-political constellations (Bourdieu, 1987; Braidotti, 2002; Fausto-Sterling, 2000). From the perspective of embodiment there is no such thing as the brain as a fully separate organ. We can think of the brain not as such but as part of, as embedded in, as being in relation to other functions and systems of the body. This is the reason I use the word 'brain-body' when I talk about the body or the brain in theories of embodiment.

Conceptualizations of the embodied brain-body vary immensely in content and scope though (Ziemke, 2001). In its weak form embodiment simply means that cognitive functions take place in a physical substratum. More elaborate versions understand the brain-body as a multilayered, multifunctional, self-organizing system consisting of interacting subsystems. This version is very common: cognition, perception, emotion, action are not separate but interact continuously and shape our understanding of the self and of the world. Another approach to the embodied brain-body emphasizes its phenomenological dimensions as the existential ground of thinking. Our bodily movements, orientations are, literally, the ground on which our mental concepts and abstractions build. 'No matter how sophisticated our abstractions become, if they are to be meaningful to us, they must retain their intimate ties to our embodied modes of conceptualization and reasoning. We can only experience what our embodiment allows us to experience. We can only conceptualize using conceptual systems grounded in our bodily experience' (Johnson, 1999, p. 81). Another widespread version of the concept of embodiment emphasizes the brain-body as an active agent absorbing, modifying, transforming social, cultural and symbolic forces. The brain-body in all these understandings is the human body. Many extend this approach to include the artificial, organismoid or humanoid body and its relations to the human body: embodiment in these accounts refers to hybrid machines which are able to act in real-time and real-space environments and not to machines which act in virtual space or in protected, experimental environments (cf. Chrisley and Ziemke, 2002; Brooks, 2001).

All these divergent approaches and countless descendant theories of embodiment propose that our conceptual and experiential systems are inextricably linked to the sensorimotor and affective functions of the brain-body. Experience starts with the affective-perceptual sensing of the 
environment and with locomotion in it. Experience is realised in the brain-body, through the brainbody, on the neuronal connections which are formed by the continuous interaction of the different bodily subsystems and the environment. From an intra-organismic perspective the embodied brain is the steadily transforming brain in a process of constantly monitoring and interacting with the totality of the body and the brain itself. The self we have, the experiences that make us cannot exist without a brain that represents its own state and the state of the body in which it is embedded (Damasio, 1999; LeDoux, 2002).

Epistemologically the perspective of the embodied brain constitutes a direct challenge to genetic reductionism, nativism and to a decontextualised and abstract understanding of the brain. But it does more than that. Developmental Systems Theory - which was an important agent in challenging genetic reductionism by advocating a holistic approach to the evolution of the embodied brain (Oyama, 2000; Lewontin, 2000b; Gottlieb, 1992) - has showed that embodiment is not just about decentring the brain into the body of the organism but mainly about decentring the whole organism itself. Rather than reducing the unit of analysis to the organism itself Developmental Systems Theory proclaims that embodiment is always dependent on intra- and inter-organismic relations. There is no embodiment if there are no other bodies around. The embodiment of the brain is the becoming embodied with other bodies and through other bodies, it is about symbiosis rather than perseverance of single organisms, as Margulis and Sagan (2003) put it. Embodiment means relationality and co-construction.

The brain of today's epoch seems to be one that is characterised by its relational architectures in an ongoing formation of brain-body matter. That every epoch has its brain means that the brain it enacts becomes also the actor of its own existential conditions. In this sense, theories of embodiment are not just abstract immaterial representations of somato-material processes. Rather they are active forces in the transformation of existing social and material realities; they even transform the very existential conditions of the brain-body itself. Hence, the embodied approach to the brain is literally embodied, it is not monitoring reality or specific neurobiological, developmental or social processes, it is the process itself: it recombines pre-existing material and creates new ways of being and new 'forms of life' (Winner, 1986; see also Papadopoulos, 2011). Theories of embodiment induce new modes of existence fostering combinations on all different levels of organization, genetic, neural, organismic, environmental/social, combinations which were not present before.

\section{The politics of embodiment: emancipation and control}

The epistemic and cultural construction of the embodied brain-body, discussed in the previous sections, corresponds to the body politics of emancipation movements which initially arose after the 1970s and 1980s. Foucault (1995) made a substantial contribution to placing the brain-body in the centre of academic debates in the humanities and social sciences, but it is feminist and queer politics (e.g. Alaimo and Hekman, 2008; Clarke and Olesen, 1998; De Lauretis, 1987), critical studies of science, technology and medicine (e.g. Bauchspies and Puig de la Bellacasa, 2009; Clarke et al., 2010; Haraway, 1991; Latimer and Schillmeier, 2009; Myers, 2008; Rapp, 2000), critiques of disembodied information systems and representational information technologies (Lilley, Lightfoot, and Amaral, 2004; Hayles, 1999) and various indigenous and antiracist movements that released the idea of the 
body as a political potentiality (Turner, 1984: 247). The topos of the embodied and emergent brainbody becomes an open field where essentialist and formulaic understandings of the workings of the brain-body are rewritten and reconfigured under the guise of their social and political significance. 'Body politics' (Blanche, Bhavnani, and Hook, 1999) directly correspond with the deployment of concept of embodiment and emergence in neuroscience, developmental science and psychology. It is impossible to establish a feasible theoretical approach to the brain-body without challenging the deterministic understanding of its material workings. Making the brain-body permeable to the pressures of the emancipation movements was coextensive with contesting the impermeability and universality of the scientific biological brain-body. In fact the emancipation discourses of the emergent brain-body infuse social antagonisms into the realm of science.

But emancipation movements through brain-body politics constitute only one of the ways embodiment and emergence figure in social practices and the cultural imaginary. At the same moment, along with emancipation discourses, the emergent and embodied brain-body captures the desire for a regenerating brain-body in the fatigued North-Atlantic societies. It is a brain-body which tries to overcome discourses of intrusion, death, and origins by viewing itself as the all-in-one solution: it is source, site, and target of its own regenerative practices. Thus, even if the topos of the emergent brain-body privileges contextuality and specificity, its logic is precisely based on an idea of neutralizing the notion of limit and context as imposed by other brain-body discourses. The emergent brain-body represents a particularly vicious form of cultural universalism: It promises healing not in terms of correction (cerebral body), protection (immune body), or the ideology of a fixed origin (hereditary body) but in terms of its very own open reconstruction and recombination.

Embodiment promises to engage with the lived pains of the body, the tamed flesh, the tortured flesh, the oppressed flesh (Scarry, 1985; Duden, 2002). But at the same time this promise is very localized in its scope: it hinges on the belief in a recombinant individual agent; a belief and a practice which interrupts and simultaneously invigorates the political dictum of neoliberal societies of the Global North: sole individuals localized in the power grids of the market which are never discernible as such. The ambivalence of the topos of the embodied and emergent brain-body is that it arose as a powerful critical practice that question the prevalent decontextualised and out-of-time individualism circulating in everyday culture as well as in neuroscience, evolutionary biology and psychology/developmental science in Global North societies. But this thrust towards undoing the individual agent was gradually appropriated in the discourse of the flexible individual that comes to replace previous ideas about the abstract rational autonomous agent (Papadopoulos, 2003). The flexible individual concentrates on its self-modification in order to achieve success in the present by neglecting broader future consequences of its actions (Schull and Zaloom, 2011). Social, subjective, neuronal flexibility is not just the target or the modus operandi of self-relationality, rather it is the very condition of embodied liberal individualism in the Global North. Control is embodied, it is exercised through being placed in a constant process of modifying our very own material existences (see Pitts-Taylor, 2010; and the editorial in Cromby, Newton, and Williams, 2011). Individuals are in a permanent process of self-maintenance; one could almost believe that we never die and we never live, we are just perpetually maintaining and working on our brains and bodies (Martin, 2010). Contemporary political governance encounters the individual as an assemblage of ideas, limbs, hitech devices, chemical substances, environmental factors which is continuously creating and re- 
creating itself, striving to achieve a specific position in a social nexus which could never be identifiable as a whole (Martin, 2002; Papadopoulos, 2008).

The ambivalence of the embodied brain-body is its double affiliation with emancipation and control at the same time: the movement towards embodiment was initiated by the pressures of critical social movements and social activism (in particular feminist, gay and antiracist movements) on the technoscientific knowledge grid that researches the brain and the body. But the liberating brain-body worlds that these emancipatory movements put in motion are gradually being appropriated in the neoliberal geoculture emerging after the 1980s. This could be understood as a failure of these emancipatory movements. But this understanding would mean that there are clean, pure, everlasting liberatory answers. This is not the case; rather the appropriation of emancipatory thinking and activism testifies for the importance and centrality of its critique in social life and its capacity to change the conditions of existence (Papadopoulos, Stephenson, and Tsianos, 2008). Against the positions that see critical thinking and activism as a marginal and marginalising discourse (e.g. Latour, 2004), the history and practice of the embodied brain-body supports a different perspective. Emancipatory movements have opened a space for performing the brain-body as embodied, a space that did not exist before, a space that came before control and had the capacity to create new liberating conditions. The existence of new libratory forms of existence forced control to change and reorganise itself in order to be able to respond to and finally appropriate these movements: the idea of the embodied brain-body was gradually appropriated into the discourse of regenerating the brain-body through its own recombination.

\section{From embodiment and emergence to plasticity and autogeneric brain-bodies}

The quest for recombination is not just an abstract ideal reverberating through the parallel discourses of social emancipation and social control; it is firmly located in the socio-technical materialities of existence. Embodiment and emergence have, for example, a crucial impact on the rearrangement of the fields of artificial intelligence and artificial machines by instigating a radical practical critique of cognitivist models in robotics (Balsamo, 1995; Hayles, 1999; Varela, Thompson, and Rosch, 1991). One of the core assumptions of these models is that it is potentially possible to duplicate the functions of the human mind and to create an artificial quasi human brain. This quasi-brain should be able to execute control over the sensorimotor subsystems and to act as a controlling device responsible for autonomous problem solving. In this view, cognition again dominates the circuits of action, affect and perception. This perspective has been proven untenable in the field of robotics, especially in relation to humanoid robots (Brooks, 1991; Hayles, 1999). Not only are we far from duplicating the human brain or from creating quasi-brains sufficient for steering humanoid systems, but the research on vision and motion has made considerable advances that question the possibility of constructing of a quasi-brain. Theories of embodiment attempt to overcome this inconsistency of cognitivist approaches: they link cognition directly to motion and perception circuits (increasingly also to affective) and question the necessity of the existence of a quasi-brain at all (Brooks, 2002). Embodiment is the key strategy for creating new emerging non-human actors from a situated perspective. 
The new humanoid robots get rid of the pressure to have consciousness implanted in their artificial brain-body by a human hand. They need only simple cognitive architectures, sophisticated sensorimotor subsystems, fast hardware and a sufficient repertoire of social-emotional skills. Inspired by animal behaviour and movement, embodied approaches to robotics use semi-open connectionist nets to link together different brain-body subsystems of humanoid machines and create new social actors. These new machines possess agency and are genuinely emergent (Sonigo, 2005): simple perceptions trigger bodily movements, bodily movements elicit cognitive procedures, in turn these organise perception, failures of the activity produce new affective states, affects intensify bodily movements and new communication scripts, which require faster responses and new more complicated cognitive procedures and so on. In the realm of situated robotics complexity is not a gift from the humans to the machines. In fact all what humans can do is to reduce complexity and simplify brain processes and body architectures. What these new machines do is far more sophisticated that what humans can produce: they increase complexity through recombining situated and embodied processes in animal-human-machine hybrids (Adam, 1998; Clark, 1998; Kember, 2003; Puig de la Bellacasa, 2009; Steels and Brooks, 1995; Suchman, 2007).

Recombination here points towards something which is more than the reconfiguration of existing embodied architectures; it evokes biotic machines that will be ultimately capable of reproducing themselves independent of human intervention. It is probably this particular dimension of a selforganised reproduction that is central to the imaginary of plasticity that starts circulating in neuroscience and popular culture (Pitts-Taylor, 2010). If every epoch has its brain - and as I argued today's epoch gravitates around the embodied brain-body - then every epoch fantasises a better brain-body to have. Embodiment and emergence open the view to the plastic brain. Recombinant plasticity is the promise that theories of embodiment and emergence bring with them but cannot fully realise. What is crucial here is not only that the brain-body is emergent and embodied but that it can also change itself. The Brain That Changes Itself is the title of Norman Doidge's (2008) New York Times bestseller. What counts is not embodiment per se but the autogeneric possibilities that the recombinant plastic brain-body release. Recombinant plasticity points towards a different model for understanding brain-body matter, one which is ultimately much more fascinated with selfreproducing organic bodies than with distributive networks, self-organised systems and bodyenvironment interactions which dominate theories of embodiment.

Plasticity here refers primarily to ecological-developmental plasticity of the brain-body and neuronal plasticity. Environmental influences (Gottlieb, Wahlsten, and Lickliter, 1998) and intrinsic processes of interaction and ecological symbiosis with other bodies (Margulis, 1998) define the range of potential phenotypes that can be actualised (Gilbert and Epel, 2009). The plastic brain-body is present to itself, 'self-generating' but also creating new forms through the incessant interactions and reconfigurations of the different participating levels of organization. And at the same time it constrained by the contingent limitations which exist in itself and in its ecology (Robert, 2004). It is the interplay between plasticity and specificity, as Steven Rose (1998) puts it, that describes the condition for inserting real life time and real life contexts in the body and the brain. The recombinant plastic brain-body is marked by the events as they occur in the multiple interactions between genetic, neural, organismic and ecological levels of existence (Gottlieb, 1992), it exists only in real-time and real-world ecologies, thus it can be only understood from an ecological-developmental perspective (Sultan, 2007; Muller, 2007). West-Eberhard's (2003) theory of developmental plasticity and Wexler's 
(2006) theory of neuroplasticity across the life-span provide solid accounts of how phenotypic variation occurs as a diversified process depending on a multitude of environmental factors, social and cultural conditions and the genetic material shaping differently brain-body matter (see also Jablonka and Lamb, 2005; Huttenlocher, 2002; Gilbert and Epel, 2009).

\section{Recombinant plasticity put to work: epigenesis and ecomorphs}

What are the concrete manifestations of the plastic brain-body? If intra-somatic and extra-somatic factors in their totality affect the development and making of the brain, then which particular factors are important in the formation of brain-body matter and which not? In order to answer this question one has to investigate the specific environmentally induced variations that affect brain-body development. This is the turn to epigenetics (Gottlieb, 2007; Robert, 2004; van Speybroeck, van de Vijver, and de Waele, 2002). 'Epigenetics is defined here as those genetic mechanisms that create phenotypic variation without altering the base-pair nucleotide sequence of the genes' (Gilbert and Epel, 2009: 12). Epigenetic factors are increasingly considered as important for conceiving how genes are (or are not) expressed in processes of development and how environmentally induced changes of the organism can be transmitted to the offspring (Gilbert and Epel, 2009; Calvanese et al., 2009; Robert, 2004). Epigenetic explanations of human development attempt to grasp the multifactorial complexity involved in extra-genetic micro-organismic processes and cellular transformation as well as in organism-environment interactions (Gottlieb, Wahlsten, and Lickliter, 1998).

The study and standardisation of epigenetic factors becomes one of the key innovations that drive basic research and applications from an evolutionary-developmental perspective (Masterpasqua, 2009; Lamb, 1994). Consider for example research on foetal development (Kiefer, 2007), on gene expression through exposure to different nutritional substances (Landecker, 2011a), the prevalence of specific types of degenerative processes associated with later life (Bandyopadhyay and Medrano, 2003) or the impact of social experiences on phenotypic variation (Champagne, 2010). Epigenesis opens up the field of research on the embodied brain-body towards different scales of geneenvironment assemblages. There are enormous variations regarding these scales and this is considered as the main challenge for further research. Different approaches deliver different answers to how each specific level interacts with all others varying from the relation between the DNA and proteins, cells, the organism and their environment (Mitchell et al., 1996; Gilbert, 2002). But what is common to all of them is that the brain-body is a plastic system shaped through the interplay of epigenetic factors and our genes.

The moment of the announcement of the human genome project, which was mentioned in the beginning of this paper, was probably one of the last instances of celebration of genetic reductionism. To the words of President Clinton that 'we are learning the language in which God created life' we should probably add: 'Let the race for epigenetics begin!' After the celebrations of the decoding of the human genome have faded and given way to scepticism, Time magazine rushed to announce a new decoding: the decoding of the human epigenome as a new major scientific discovery (Time, 8 December 2009). Fifty or even forty years earlier the gene was an absent reference in the widespread scientific fantasies and popular imagination of the brain-body: as retired inspector Tracy Waterhouse says in Kate Atkinson's (2010: 251) last novel 'if you said "gene" in the seventies people 
thought Levi's or Wranglers'. But very quickly it became the floating signifier in the genocentric imaginary dominating the end of the previous century. Another turn now: What only few years earlier would have been formulated as 'Why your DNA is your destiny' or 'Your genes, your choices' (Baker and American Association for the Advancement of Science, 1997) today it reads: 'Why your DNA isn't your destiny' (Time, 6 January 2010). Now the task is to codify epigenetic factors, sort out substances and environmental conditions which inhibit or promote specific gene expressions, standardize the mechanics of the environment-organism interplay and the ecology-development-gene interplay.

The outcome of this interplay is phenotypic variation: ecomorphs. Ecomoprhs are different phenotypes depending on the influences of contingent ecological and relational factors in which an organism is embedded in (Wainwright and Reilly, 1994). I use the term here in an extended way: Ecomorphs are standardizations of effects that epigenetic developmental factors (be it intraorganismic or extra-organismic) have on a recombinant plastic organism. Ecomorphs are here understood as stable configurations of ecological-developmental influences and the genetic code. The term is deployed in this context to describe the outcome of research on epigenetics that can be standardized, classified and catalogued with the use of bioinformatics and subsequently made available to the public (or become a marketised as commodity). Ecomorphs are then systematizations of what Hannah Landecker (Landecker, 2011b) describes as the constitution of the environment and the social as a biologically meaningful signal in epigenetic research. Reducing and classifying the environment to a mere signal that induces drastic changes in genetic function is the crucial step in developing classifications of causal relations between the environment and the gene. Ecomorphs can be then considered as classifications of the causal coupling between certain environemntal situations and a specific expression of genes. Ecomorphs are in this sense the smallest knowledge unit that has biovalue in epigenetic research and can be used for further basic research or other applications. Maps of ecomorphs are the product of epigenetics in the same way a map of genes in the human genome database was the product of DNA sequencing. But probably the number of ecomorphs will be far more than the approximately 25000 human genes. Ecomorphs will materialise the vision of truly learning how to create life and how to efficiently remake the brain-body. 
Table 1: Diagram of different approaches to the brain-body

\begin{tabular}{|c|c|c|c|c|c|}
\hline & behaviourism & cognitivism & connectionism & embodiment & autogeneric \\
\hline $\begin{array}{l}\text { underlying } \\
\text { metaphor }\end{array}$ & $\begin{array}{l}\text { mechanical } \\
\text { interface }\end{array}$ & digital computer & network & $\begin{array}{l}\text { animal-human- } \\
\text { machine hybrids }\end{array}$ & $\begin{array}{c}\text { autonomous } \\
\text { machines }\end{array}$ \\
\hline modelled on & $\begin{array}{l}\text { basic animal } \\
\text { physiological } \\
\text { processes }\end{array}$ & $\begin{array}{c}\text { controlled problem } \\
\text { solving }\end{array}$ & $\begin{array}{l}\text { distributive } \\
\text { processes }\end{array}$ & $\begin{array}{l}\text { body- } \\
\text { environment } \\
\text { interactions }\end{array}$ & $\begin{array}{l}\text { reproduction of } \\
\text { organic bodies }\end{array}$ \\
\hline $\begin{array}{l}\text { functioning } \\
\text { principle }\end{array}$ & stimulus-response & $\begin{array}{l}\text { universal } \\
\text { algorithms }\end{array}$ & nodes and weights & $\begin{array}{c}\text { emergent } \\
\text { architectures }\end{array}$ & plasticity \\
\hline $\begin{array}{l}\text { organisation } \\
\text { principle }\end{array}$ & black box & centralism & decentralism & contextualism & $\begin{array}{l}\text { recombination } \\
\text { and nonhuman } \\
\text { agency } \\
\end{array}$ \\
\hline $\begin{array}{l}\text { supposed biological } \\
\text { substratum }\end{array}$ & $\begin{array}{c}\text { physiological } \\
\text { processes }\end{array}$ & $\begin{array}{l}\text { genes and brain } \\
\text { modules }\end{array}$ & neural circuits & $\begin{array}{c}\text { organism- } \\
\text { environment } \\
\text { assemblages }\end{array}$ & biotic machines \\
\hline explanans & determinism & nativism & connectivity & relationality & epigenesis \\
\hline $\begin{array}{l}\text { dominant cultural- } \\
\text { political conditions }\end{array}$ & Fordist state & liberal democracies & \multicolumn{2}{|c|}{ neoliberal geoculture } & $\begin{array}{l}\text { postliberal } \\
\text { enclosures }\end{array}$ \\
\hline $\begin{array}{l}\text { social movements } \\
\text { and activism }\end{array}$ & $\begin{array}{c}\text { workers } \\
\text { movement; social } \\
\text { liberalism }\end{array}$ & $\begin{array}{c}\text { Chomskyan liberal } \\
\text { egalitarianism; civil } \\
\text { rights; identity } \\
\text { politics }\end{array}$ & \multicolumn{2}{|c|}{$\begin{array}{l}\text { alter-globalization movements; situated } \\
\text { knowledges; postmodern perspectivism; } \\
\text { reverse engineering }\end{array}$} & $\begin{array}{c}\text { alter-ontological } \\
\text { activism and the } \\
\text { commoning of } \\
\text { matter }\end{array}$ \\
\hline
\end{tabular}

\section{The politics of plasticity and the commoning of knowledge}

In the previous sections I tried to sketch a diagram of different approaches to brain-body matter and tell the story of the brain-body from the perspective of its plastic capacity to recombine itself. The recombinant plastic brain-body is literally in a process of auto-generation: it becomes a political agent that operates in the very material constraints of the environmental, social and biochemical conditions that make it happen. Plastic brain-body matter becomes the source and target for freeing the brainbody from the constraints of its previous materialisations in behaviousrism, cognitivism, connectionism and embodiment as described throughout this paper (see also a summary of these different versions of the brain-body in Table 1). The imaginary of recombinant plasticity is not only a radical challenge to 'Western thought', it becomes an element for the ultimate regeneration and actualization of Western thought, literally - the pop story goes like this: 'We'll be able to direct changes: stimulate new brain cells and networks where and when we need them; turn genes off and on at will to repair brain damage, restore function, and optimize performance; and rewire our brains to manipulate memory and even reverse dementia and mental retardation' (Horstman and Scientific American, 2010: 8). Parisi and Terranova (2000) remind us that every configuration of the brainbody as a specific type of organism (in our case here it is the self-healing and recombinant plastic organism) is the result of the conjoined action of capital and technoscience in Western capitalist societies. 
The story of the recombinant plastic brain-body is concomitant with appropriating the production of ecomorphs and inserting them into free market structures through the corporatization and privatization of brain-body research and the proprietizarization of the epigenome (a process similar to the ongoing biomedicalization of the body explored in Clarke et al., 2010; and Kippax and Stephenson, 2010). In this process of marketisation it is not only the private sector that plays an important role but also the state and other civil society organisations. What we see today is the formation of vertical actors that comprise of parts of a certain state, parts of global international actors (such as the WHO), together with specific private corporations, certain charitable foundations and associations of civil society. These vertical actors which are neither purely private nor public but a mix of both attempt to control bioproduction and compete with other vertical actors in the dissemination and application of knowledge (for further discussion see Kippax and Stephenson, 2010). It is in these conditions - which we elsewhere called postliberal vertical aggregates (Stephenson, 2011; Papadopoulos, Stephenson, and Tsianos, 2008) - that bioproduction and the capitalisation of ecomorphs unfolds. The reduction of ecomoprhs to biovalue cannot be easily criticised from the vantage point of an opposition between the public vs. private interests. The easy explanation of the private appropriation of public goods no longer holds; neither is it possible to argue that there is a clear cut distinction between private and civil society interests. Rather, it is a combination of public, private and civil society aggregates that appropriate and create enclosures of knowledge that is essentially cooperatively produced in the commons and through the commons (Bollier, 2003; Peuter and Dyer-Witheford, 2010).

But the recombinant plastic brain-body caters not only for those who attempt to integrate non-reductionist and non-determinist experimentation with epigenetics into the workings of these postliberal capitalist forms of bioproduction, but also for those who see in the plastic brain-body the possibility for developing new forms of resistance and new liberating visions of our neural selves (Malabou, 2008; S. Watson, 1998). This emancipatory side of the imaginary of recombinant plasticity could even entail the biggest fantasy of all which is so nicely and fallaciously described in the work of Malabou (2008). Recombinant plasticity should go as far as to become the self-governed process of challenging the very plasticity of our brain-body: 'To cancel the fluxes, to lower our self-controlling guard, to accept exploding from time to time: this is what we should do with our brain' (Malabou, 2008: 79). If we only had a new political consciousness of the brain, Malabou argues, we would be able to steer neuroscience towards a democratic course and achieve neuronal liberation. Here the imaginary of recombinant plasticity serves the opposite of what the postliberal aggreagtes perform: it encloses the brain-body in the fantasy of a grand coherent historical actor that is able to challenge the neoliberal domination of the brain-body and return the brain to the hands of the public.

Plasticity has something to offer for those who see the plastic brain-body instrumentally as a source for the mere regeneration of late capitalist power and wealth as well as for those who see in the very ontology of the plastic brain-body the promise of a grand political liberation. It even caters for those in-between who see in it a new form of micropolitical regulation through the proliferation of neuronal subjectivities (Abi-Rached and Rose, 2010; N. Rose, 2001; Wilson, 2004): the recombinant plastic brain-body as the main instrument for neuro-governance. The plastic brain-body has something for everyone. Its promise is its capacity to become enclosed in the market or in fantasies of political liberation or in ordinary processes of governance. Its promise is its universal appeal. But isn't every universalism a retreat to a control regime that operates through 
disembodiment and decontextualisation? Aren't at the end all these different types of enclosure different variants of ethnocentric universalist political practice?

Is it possible to escape these various ethnocentric reincarnations of universalism and incorporeality of the imaginary of recombinant plasticity? As with so many other technologies and scientific knowledges we know that no form of control can exist without seizing the everyday experience of people and things. And simultaneously no gesture of freedom and justice and care can start without being firmly located in everyday life and in ordinary materiality (Papadopoulos, 2010a, 2010b, 2011; Puig de la Bellacasa, 2010, 2011; Stephenson and Papadopoulos, 2006). It is in the everyday reclaiming and multiplication of brain-body knowledge and practice that the possibility for defying the universalisms of the imaginary of recombinant plasticity lays. In this piece I tried to show that the type of brain-body we believe that we have is the brain-body that enacts its own real existence and shapes itself. If the plastic brain-body is a brain-body open to development and its ecologies and if development and ecology are processes that are essentially located in the everyday and do not belong to nobody (that is they are neither public, nor private nor state owned), then the plastic brain-body can only be truly enacted outside of the enclosures of capitalisation, grand liberation, and neuro-governance. The most crucial question that the emergence of the imaginary of recombinant plasticity brings with it is probably about the return of the brain-body to the everyday common spaces in which it is created and through which it can only exist: the recombinant plastic brain-body is, borrowing Peter Linebaugh's (2008) term, about the commoning of the brain-body.

\section{References}

Abi-Rached, J. M., and Rose, N., (2010), The birth of the neuromolecular gaze, History of the Human Sciences, 23(1), 11-36.

Adam, A. (1998), Artificial Knowing. Gender and the Thinking Machine, New York: Routledge.

Alaimo, S., and Hekman, S. J., (eds), (2008), Material Feminisms, Bloomington, Ind.: Bloomington, IN: Indiana University Press.

Atkinson, K., (2010), Started Early, Took My Dog, London: Doubleday.

Baker, C., and American Association for the Advancement of Science, (1997), Your genes, your choices. Exploring the issues raised by genetic research. Washington, D.C.: American Association for the Advancement of Science.

Baldwin, J. M. (1897), Social and ethical interpretations in mental development. A study in social psychology. New York: Macmillan.

Balsamo, A. (1995), Forms of technological embodiment: Reading the body in contemporary culture. In M. Featherstone and R. Burrows (eds), Cyberspacelcyberbodies/cyberpunk: cultures of technological embodiment (pp. 215-237), London: Sage.

Bandyopadhyay, D., and Medrano, E. E. (2003), The emerging role of epigenetics in cellular and organismal aging. Experimental Gerontology, 38(11-12), 1299-1307.

Barad, K. (1998), Getting real: technoscientific practices and the materialization of reality. differences: $A$ Journal of Feminist Cultural Studies, 10(2), 87-126.

Bauchspies, W., and Puig de la Bellacasa, M. (2009), Special issue: Re-tooling subjectivities, exploring the possible with Feminist Science and Technology Studies. Subjectivity, 28(1).

Beaulieu, A. (2003), Brains, Maps and the New Territory of Psychology. Theory and Psychology, 13(4), 561-568. 
Blanche, M. T., Bhavnani, K.-K., and Hook, D. (eds), (1999), Body politics. Power, knowledge and the body in social sciences. Johannesburg: Histories of the Present Press.

Bollier, D. (2003), Silent theft. The private plunder of our common wealth. London: Routledge.

Bordo, S. (1990), Reading the slender body. In M. Jacobus, E. F. Keller and S. Shuttleworth (eds), Body/politics : women and the discourses of science (pp. 83-112), New York: Routledge.

Bourdieu, P. (1987), Sozialer Sinn: Kritik der theoretischen Vernunft. Frankfurt am Main: Suhrkamp.

Braidotti, R. (2002), Metamorphoses : towards a materialist theory of becoming. Cambridge ; Malden, MA: Polity ; Blackwell.

Breckenridge, C. A., and Vogler, C. (2001), The Critical Limits of Embodiment: Disability's Criticism. Public Culture, 13(3), 349-357.

Brooks, R. A. (1991), Intelligence without representation. Artificial Intelligence, 47, 139-159.

Brooks, R. A. (2001), Künstliche Intelligenz und Roboter-Entwicklung. In A. Münkel and Sonderausstellung Computer.Gehirn (eds), Computer.Gehirn: Was kann der Mensch? Was können die Computer? Begleitpublikation zur Sonderausstellung im Heinz-Nixdorf-MuseumsForum (pp. 14-37), Paderborn: Schöningh.

Brooks, R. A. (2002), Flesh and machines : how robots will change us. New York: Pantheon Books.

Bruner, J. S. (1967), Preface. Soviet Psychology, 5, 3-5.

Bruner, J. S., Goodnow, J., and Austin, G. A. (1956), A study of thinking. New York: Wiley.

Calvanese, V., Lara, E., Kahn, A., and Fraga, M. F. (2009), The role of epigenetics in aging and agerelated diseases. Ageing Research Reviews, 8(4), 268-276.

Champagne, F. A. (2010), Epigenetic influence of social experiences across the lifespan. Developmental Psychobiology, 52(4), 299-311.

Changeux, J.-P. (1997), Neuronal man : the biology of mind. Princeton, N.J.: Princeton University Press.

Chrisley, R., and Ziemke, T. (2002), Embodiment. In L. Nadel (Ed.), Encyclopedia of Cognitive Science (pp. 1102-1108), London: Macmillan Publishers.

Churchland, P. S. (1986), Neurophilosophy : toward a unified science of the mind-brain. Cambridge, Mass.: MIT Press.

Clark, A. (1997), Being there : putting brain, body, and world together again. Cambridge, Mass.: MIT Press.

Clark, A. (1998), Where Brain, Body and World Collide. Daedalus, 127(2), 257-280.

Clarke, A., Mamo, L., Fosket, J. R., Fishman, J. R., and Shim, J. K. (eds), (2010), Biomedicalization: technoscience, health, and illness in the U.S. Durham: Duke University Press.

Clarke, A., and Olesen, V. L. (1998), Revisioning women, health and healing: feminist, cultural, and technoscience perspectives. New York: Routledge.

Cooper, M. (2008), Life as surplus. Biotechnology and capitalism in the neoliberal era. Seattle: University of Washington Press.

Crimp, D. (1988), How to have promiscuity in an epidemic. In D. Crimp and L. Bersani (eds), AIDS : cultural analysis, cultural activism (pp. 237-271), Cambridge, Mass.: MIT Press.

Cromby, J. (2004), Between Constructionism and Neuroscience: The Societal Co-constitution of Embodied Subjectivity. Theory and Psychology, 14(6), 797-821.

Cromby, J. (2007), Integrating social science with neuroscience: Potentials and problems. BioSocieties, 2, 149-169.

Cromby, J., Newton, T., and Williams, S. (2011), Special Issue 'Subjectivity and Neuroscience'. Subjectivity, 4(3).

Csordas, T. J. (1994a), Introduction: the body as representation and being-in-the-world. In T. J. Csordas (Ed.), Embodiment and experience : the existential ground of culture and self (pp. 1-24), Cambridge ; New York: Cambridge University Press.

Csordas, T. J. (Ed.), (1994b), Embodiment and experience : the existential ground of culture and self. Cambridge ; New York: Cambridge University Press.

Damasio, A. R. (1999), The feeling of what happens : body and emotion in the making of consciousness. New York: Harcourt Brace. 
Damasio, A. R. (2004), Looking for Spinoza : joy, sorrow and the feeling brain. London: Vintage.

De Lauretis, T. (1987), Technologies of gender. Essays on theory, film, and fiction. Bloomington, IN: Indiana University Press.

Deleuze, G., and Guattari, F. (1987), A thousand plateaus : capitalism and schizophrenia. Minneapolis: University of Minnesota Press.

Dennett, D. C. (1995), Darwin's dangerous idea : evolution and the meanings of life. New York: Simon and Schuster.

Dewey, J. (1999), Democracy and education : an introduction to the philosophy of education. New York: Free Press.

Doidge, N. (2008), The brain that changes itself: stories of personal triumph from the frontiers of brain science. London: Penguin.

Duden, B. (2002), Die Gene im Kopf - der Fötus im Bauch : Historisches zum Frauenkörper. Hannover: Offizin.

Dumit, J. (2004), Picturing personhood : brain scans and biomedical identity. Princeton, N.J.: Princeton University Press.

Edelman, G. M. (1989), Neural Darwinism : the theory of neuronal group selection. Oxford: Oxford University Press.

Edelman, G. M. (1992), Bright air, brilliant fire : on the matter of the mind. New York, N.Y.: Basic Books.

Edelman, G. M., and Tononi, G. (2000), A universe of consciousness : how matter becomes imagination (1st ed.), New York, NY: Basic Books.

Elman, J. L., Bates, E., Johnson, M., Karmiloff-Smith, A., Parisi, D., and Plunkett, K. (1996), Rethinking innateness : a connectionist perspective on development. Cambridge, Mass.: MIT Press.

Fausto-Sterling, A. (2000), Sexing the body : gender politics and the construction of sexuality. New York, NY: Basic Books.

Fodor, J. A. (1983), The Modularity of mind : an essay on faculty psychology. Cambridge, Mass.: MIT Press. Foucault, M. (1995), Der Wille zum Wissen : Sexualität und Wahrheit, Band 1. Frankfurt a.M.: Suhrkamp.

Frank, A. (1991), For a sociology of the body. An analytical review. In M. Featherstone, M. Hepworth and B. S. Turner (eds), The body : social process and cultural theory (pp. 36-102), London: Sage.

Franks, D. D. (2010), Neurosociology: The nexus between neuroscience and social psychology. New York: Springer.

Gardner, H. (1987), The mind's new science. A history of cognitive revolution. New York: Basic.

Gilbert, S. F. (1997), Bodies of knowledge: Biology and the intercultural university. In P. J. Taylor, S. E. Halfon and P. N. Edwards (eds), Changing life : genomes, ecologies, bodies, commodities (pp. 3655), Minneapolis, MN: University of Minnesota Press.

Gilbert, S. F. (2002), The Genome in Its Ecological Context: Philosophical Perspectives on Interspecies Epigenesis. Annals- New York Academy of Sciences, 981, 202-218.

Gilbert, S. F., and Epel, D. (2009), Ecological developmental biology : integrating epigenetics, medicine, and evolution. Sunderland, Mass.: Sinauer Associates.

Gottlieb, G. (1992), Individual development and evolution : the genesis of novel behavior. New York: Oxford University Press.

Gottlieb, G. (1997), Synthesizing nature-nurture : prenatal roots of instinctive behavior. Mahwah, N.J.: Lawrence Erlbaum Associates.

Gottlieb, G. (2007), Probabilistic epigenesis. Developmental Science, 10(1), 1-11.

Gottlieb, G., Wahlsten, D., and Lickliter, R. (1998), The significance of biology for human development: A developmental psychobiological systems view. In W. Damon and R. M. Lerner (eds), Handbook of child psychology. Vol. I: Theoretical models of human development (pp. 233-273), New York: Wiley.

Gould, S. J. (1977), Ontogeny and phylogeny. Cambridge, Mass.: Belknap Press of Harvard University Press.

Haraway, D. J. (1991), Simians, cyborgs, and women : the reinvention of nature. New York: Routledge. 
Harré, R. (1996), The necessity of personhood as embodied being. Theory and Psychology, 5, 369-373.

Hayles, N. K. (1999), How we became posthuman : virtual bodies in cybernetics, literature, and informatics. Chicago, Ill.: University of Chicago Press.

Heidegger, M. (1993), Sein und Zeit. Tübingen: Niemeyer.

Horstman, J., and Scientific American. (2010), The Scientific American brave new brain. San Francisco, Calif.: Jossey-Bass.

Huttenlocher, P. R. (2002), Neural plasticity. The effects of environment on the development of the cerebral cortex. Cambridge, MA: Harvard University Press.

Irigaray, L. (1985), This Sex Which Is Not One. Ithaca, NY: Cornell University Press.

Jablonka, E., and Lamb, M. J. (2005), Evolution in four dimensions. Genetic, epigenetic, behavioral, and symbolic variation in the history of life. Cambridge, Mass.: MIT Press.

Johnson, M. L. (1999), Embodied reason. In G. Weiss and H. F. Haber (eds), Perspectives on embodiment. The intersections of culture and nature (pp. 81-102), London: Routledge.

Joyce, K. (2005), Appealing Images: Magnetic Resonance Imaging and the Production of Authoritative Knowledge. Social Studies of Science, 437-462.

Karmiloff-Smith, A. (1992), Beyond modularity : a developmental perspective on cognitive science. Cambridge, Mass.: MIT Press.

Kember, S. (2003), Cyberfeminism and artificial life. London: Routledge.

Kiefer, J. C. (2007), Epigenetics in development. Developmental Dynamics, 236(4), 1144-1156.

Kippax, S., and Stephenson, N. (2010), Infectious diseases and globalisation. In B. Turner (Ed.), The Routledge international handbook of globalization studies (pp. 205-226), Abingdon: Routledge.

Lakoff, G., and Johnson, M. L. (1999), Philosophy in the flesh : the embodied mind and its challenge to Western thought. New York: Basic Books.

Lamb, M. J. (1994), Epigenetic inheritance and aging. Rev. Clin. Gerontol., 4, 97-105.

Landecker, H. (2011a), Food as exposure: Nutritional epigenetics and the new metabolism. BioSocieties, advance online publication, March 7, 2011, doi:10.1057/biosoc.2011.1051.

Landecker, H. (2011b), Food is licking is plastic: The social as signal in environmental epigenetics. Paper presented at the Workshop Anticipation: Exploring Technoscience, Life, Affect, Temporality, San Francisco, USA, March, 27-29, 2011.

Latimer, J., and Schillmeier, M. W. J. (2009), Un/knowing bodies. Malden, MA ; Oxford: Blackwell.

Latour, B. (2004), Why Has Critique Run out of Steam? From Matters of Fact to Matters of Concern. Critical Inquiry, 30(2), 225-248.

Leder, D. (1990), The absent body. Chicago: University of Chicago Press.

LeDoux, J. E. (2002), Synaptic self: how our brains become who we are. London: Macmillan.

Lewontin, R. C. (2000a), The triple helix : gene, organism, and environment. Cambridge, Mass.: Harvard University Press.

Lewontin, R. C. (2000b), The triple helix : gene, organism, and environment. Cambridge, Mass.: Harvard University Press.

Liben, L. S. (1999), Developing an understanding of external spatial representations. In I. E. Sigel (Ed.), Development of mental representation : theories and applications (pp. 297-321), Mahwah, NJ: L. Erlbaum Associates.

Lilley, S., Lightfoot, G., and Amaral, P. (2004), Representing organization : knowledge, management, and the information age. Oxford: Oxford University Press.

Linebaugh, P. (2008), The Magna Carta manifesto : liberties and commons for all. Berkeley, Calif.: University of California Press.

Littlefield, M. (2009), Constructing the Organ of Deceit. Science, Technology and Human Values, 34(3), 365-392.

Malabou, C. (2008), What should we do with our brain? New York: Fordham University Press.

Margulis, L. (1998), The symbiotic planet : a new look at evolution. London: Weidenfeld and Nicolson. 
Margulis, L., and Sagan, D. (2003), Acquiring genomes. A theory of the origins of species. New York: Basic Books.

Martin, E. (1990), Towards an anthropology of immunology: The body as nation state. Medical Anthropology Quarterly, 4, 410-426.

Martin, E. (1992), The end of the body? American Ethnologist, 19(1), 121-140.

Martin, E. (2002), "Flexible Körper." Wissenschaft und Industrie im Zeitalter des flexiblen Kapitalismus. In B. Duden and D. Noeres (eds), Auf den Spuren des Körpers in einer technogenen Welt (pp. 29-54), Opladen: Leske + Budrich.

Martin, E. (2010), Self-making and the brain. Subjectivity, 3(4).

Masterpasqua, F. (2009), Psychology and Epigenetics. Review of General Psychology, 13, 194-201.

Merleau-Ponty, M. (1966), Phänomenologie der Wahrnehmung. Berlin: De Gruyter.

Mitchell, A. R., Jeppesen, P., Nicol, L., Morrison, H., and Kipling, D. (1996), Epigenetic control of mammalian centromere protein binding: does DNA methylation have a role? Journal of Cell Science, 109, 2199-2206.

Mueller III, R. S. (2002, 30 May), Text: Excerpts From Director's Briefing on Plans to Transform the U.S. Federal Bureau of Investigation. New York Times.

Muller, G. B. (2007), Evo-devo: extending the evolutionary synthesis. Nature Reviews Genetics, 8(12), 943-949.

Myers, N. (2008), Molecular Embodiments and the Body-work of Modeling in Protein Crystallography. Social Studies of Science, 38, 163-200.

Overton, W. F. (1998), The arrow of time and cycles of time. Concepts of change, cognition and embodiment. Psychological Inquiry, 5, 215-237.

Oyama, S. (2000), The ontogeny of information : developmental systems and evolution (2nd ed.), Durham, N.C.: Duke University Press.

Papadopoulos, D. (2003), The ordinary superstition of subjectivity. Liberalism and technostructural violence. Theory and Psychology, 13(1), 73-93.

Papadopoulos, D. (2008), In the ruins of representation: Identity, individuality, subjectification. British Journal of Social Psychology, 47(1), 139-165.

Papadopoulos, D. (2010a), Activist materialism. Deleuze Studies, 4, 64-83.

Papadopoulos, D. (2010b), Insurgent posthumanism. Ephemera: Theory and Politics in Organization, 10(2), 134-151.

Papadopoulos, D. (2010c), L.S. Wygotski. Werk und Rezeption (2nd ed.), Berlin: Lehmanns Media.

Papadopoulos, D. (2011), Alter-ontologies: Towards a constituent politics in technoscience. Social Studies of Science, 41(2), 177-201.

Papadopoulos, D., Stephenson, N., and Tsianos, V. (2008), Escape routes. Control and subversion in the 21st century. London: Pluto Press.

Parisi, L., and Terranova, T. (2000), Heat-Death, Emergence and Control In Genetic Engineering And Artificial Life. CTheory, http://www.ctheory.net/articles.aspx?id=127, date last accessed: 5.2.2009.

Peuter, G. d., and Dyer-Witheford, N. (2010), Commons and Cooperatives. Affinities: A Journal of Radical Theory, Culture, and Action, 4(1), 30-56.

Pinker, S. (1997), How the mind works. New York: Norton.

Pitts-Taylor, V. (2010), The Plastic Brain: Neoliberalism and the Neuronal Self. Health: Interdisciplinary Studies in Health, Illness and Medicine, 14(6), 635-652.

Puig de la Bellacasa, M. (2009), Power to touch: The remaking of sensual experience and the politics of speculative constructivism. Subjectivity, 28(1), 297-315.

Puig de la Bellacasa, M. (2010), Ethical doings in naturecultures. Ethics, Place and Environment. A Journal of Philosophy and Geography, 13(3), 151-169.

Puig de la Bellacasa, M. (2011), Matters of care in technoscience. Assembling neglected things Social Studies of Science. 
Rapp, R. (2000), Testing women, testing the fetus : the social impact of amniocentesis in America. New York: Routledge.

Robert, J. S. (2004), Embryology, epigenesis, and evolution. Taking development seriously. Cambridge, UK: Cambridge University Press.

Roberts, C., Kippax, S., Spongberg, M., and Crawford, J. (1996), "Going Down": Oral sex, Imaginary bodies and HIV. Body and Society, 2, 107-124.

Rose, N. (2001), The politics of life itself. Theory, Culture and Society, 18(6), 1-30.

Rose, S. (1998), Lifelines : biology beyond determinism. Oxford ; New York: Oxford University Press.

Sampson, E. E. (1996), Establishing embodiment in psychology. Theory and Psychology, 6(4), 601-624.

Sandbothe, M. (1998), Die Verzeitlichung der Zeit : Grundtendenzen der modernen Zeitdebatte in Philosophie und Wissenschaft. Darmstadt: Wissenschaftliche Buchgesellschaft.

Scarry, E. (1985), The body in pain : the making and unmaking of the world. New York: Oxford University Press.

Scholl, B. J., and Leslie, A. M. (1999), Modularity, development, and 'Theory of Mind'. Mind and Language, 14(1), 131-153.

Schull, N., and Zaloom, C. (2011), The Shortsighted Brain: Neuroeconomics and the Governance of Choice in Time. Social Studies of Science.

Scott, J. W. (2001), Die Zukunft von gender. Fantasien zur Jahrtausendwende. In C. Honegger and A. Caroline (eds), Gender - die Tücken einer Kategorie : Joan W.Scott, Geschichte und Politik; Beiträge zum Symposion anlässlich der Verleihung des Hans-Sigrist-Preises 1999 der Universität Bern an Joan W. Scott (pp. 39-63), Zürich: Chronos.

Shenk, D. (2010), The genius in all of us : the new science of genes, talent and human potential. London: Icon.

Sonigo, P. (2005), The robot and the forest. Current Sociology, 53(2), 311-322.

Star, S. L. (1989), Regions of the mind. Brain research and the quest for scientific certainty. Stanford, Calif.: Stanford University Press.

Steels, L., and Brooks, R. A. (1995), The artificial life route to artificial intelligence : building embodied, situated agents. Hillsdale, N.J.: L. Erlbaum Associates.

Stephenson, N. (2011), Emerging Infectious Disease/Emerging forms of Biological Sovereignty. Science, Technology and Human Values.

Stephenson, N., and Papadopoulos, D. (2006), Analysing everyday experience. Social research and political change. London: Palgrave Macmillan.

Suchman, L. A. (2007), Human-machine reconfigurations. Plans and situated actions (2nd ed.), Cambridge: Cambridge University Press.

Sultan, S. E. (2007), Development in context: the timely emergence of eco-devo Trends in Ecology and Evolution, 22(11), 575-582

Thelen, E., and Smith, L. B. (1994), A dynamic systems approach to the development of cognition and action. Cambridge, Mass.: MIT Press.

Tolman, E. C. (1954), A psychological model. In T. Parsons and E. A. Shils (eds), Toward a general theory of action (pp. 277-361), Cambridge, MA: Harvard University Press.

Turner, B. S. (1984), The body and society : explorations in social theory. Oxford, Oxfordshire ; New York, NY: B. Blackwell.

van Speybroeck, L., van de Vijver, G., and de Waele, D. (eds), (2002), From epigenesis to epigenetics. The genome in context. Annals of the New York Academy of Sciences, Volume 981. New York: New York Academy of Sciences.

Varela, F. J., Thompson, E., and Rosch, E. (1991), The embodied mind : cognitive science and human experience. Cambridge, Mass.: MIT Press.

Vygotsky, L. S. (1987), The collected works of L.S. Vygotsky. Vol. 1: Problems of general psychology. New York: Plenum.

Wainwright, P. C., and Reilly, S. M. (eds), (1994), Ecological morphology. Integrative organismal biology. Chicago: University of Chicago Press. 
Watson, J. B. (1913), Psychology as the behaviorists views it. Psychological Review, 20, 158-177.

Watson, S. (1998), The Neurobiology of Sorcery: Deleuze and Guattari's Brain. Body and Society, 4(4), 23-45.

Weeks, J. (1995), Invented Moralities: Sexual Values in the Age of Uncertainty. Cambridge: Polity Press.

West-Eberhard, M. J. (2003), Developmental plasticity and evolution. Oxford: Oxford University Press.

Wexler, B. E. (2006), Brain and culture : neurobiology, ideology, and social change. Cambridge, Mass. ; London: MIT Press.

Wilson, E. A. (1998), Neural geographies : feminism and the microstructure of cognition. New York: Routledge.

Wilson, E. A. (2004), Psychosomatic. Feminism and the neurological body. Durham, N.C.: Duke University Press.

Winner, L. (1986), The whale and the reactor : a search for limits in an age of high technology. Chicago: University of Chicago Press.

Wittgenstein, L. (1958), Philosophical investigations. New York: Prentice Hall.

Woodworth, R. S. (1921), Psychology. New York: Holt.

Woodworth, R. S. (1938), Experimental psychology. New York: Holt.

Wygotski, L. S. (1987), Ausgewählte Schriften. Bd. 2: Arbeiten zur psychischen Entwicklung der Persönlichkeit. Köln: Pahl-Rugenstein.

Ziemke, T. (2001), Are Robots Embodied? Paper presented at the First International Workshop on Epigenetic Robotics: Modeling Cognitive Development in Robotic Systems, Lund University Cognitive Studies. 